Dept. of Food Hygiene, Animal Health Research Institute, Assiut Regional Laboratory, Egypt.

\title{
INCIDENCE OF ENTEROTOXIGENIC STAPHYLOCOCCUS AUREUS IN SOME READY-TO- EAT MEAT SANDWICHES IN ASSUIT CITY WITH SPECIAL REFERENCE TO METHICILLIN RESISTANT STAPHYLOCOCUUS AUREUS STRAINS
}

(With 4 Tables)

By

\section{SOHAILA FATHI HASSAN ALI and DOAA MOHAMMED ABD-EL-AZIZ*}

* Dept. of Food Hygiene, Faculty of Veterinary Medicine, Assiut University (Received at 15/3/2011)

مدى تواجد المكور العنقودى الأهبى المفرز للسموم في بعض اللحوم المجهزة

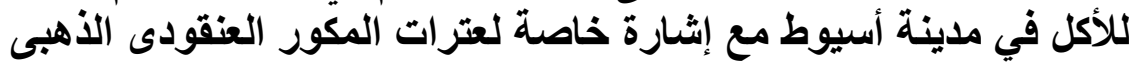
المقاوم للميثيسيللين

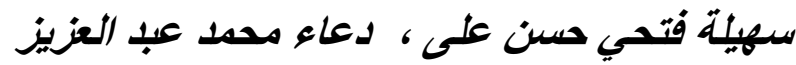

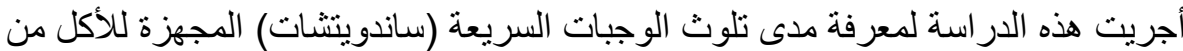

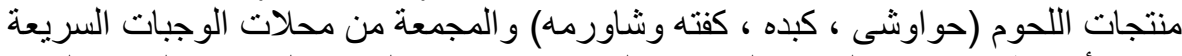

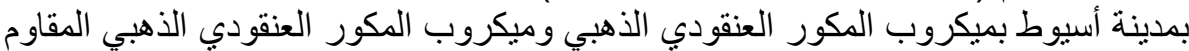

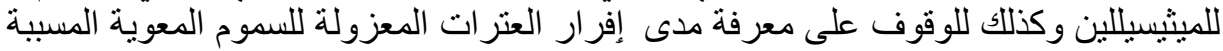

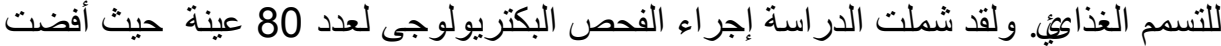

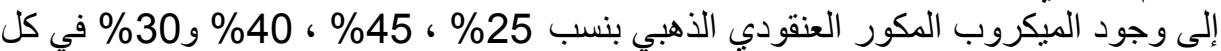

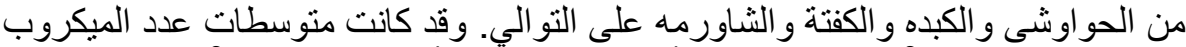

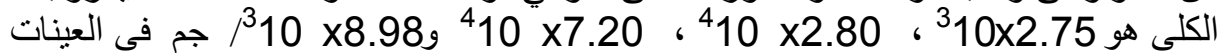

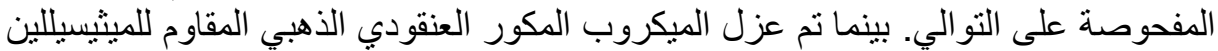

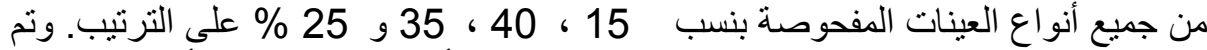

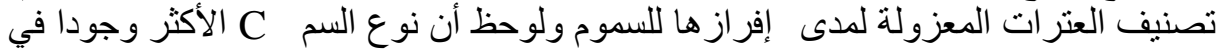

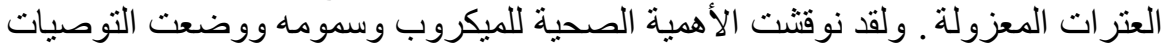
اللازمة لسلامة المستهلك و المنتج. 


\section{SUMMARY}

A total of 80 random samples of ready-to-eat meat sandwiches represented as 20 each of hawawshy, liver, kofta and shawarma that retailed from various fast food restaurants in Assiut city were examined for contamination with $S$. aureus and methicillin-resistant $S$. aureus in association with its enterotoxigenicity. $S$. aureus strains were recovered from 25, 45, 40 and 30\% of the examined hawawshy, liver, kofta and shawarma samples, respectively. While, the average counts were $2.75 \times 10^{3}, 2.80 \times 10^{4}, 7.20 \times 10^{4}$ and $8.98 \times 10^{3} \mathrm{cfu} / \mathrm{g}$ of the examined samples, respectively. Whereas, MRSA strains were isolated from 15, 40,35 and $25 \%$ of the same examined samples, respectively. Eight out of twelve strains of MRSA were isolated from liver (4 strains), shawarma (3 strains) and only one strain from kofta proved to be enterotoxigenic, while the strains isolated from hawawshy failed to produce any enterotoxins. All the 8 strains produced enterotoxins $\mathrm{C}$, while, 3 strains isolated from shawarma produced $\mathrm{CD}, \mathrm{ACD}$ and ABCDE enterotoxins, in addition the only strain isolated from kofta can produce $\mathrm{CE}$ enterotoxins. The results showed that enterotoxin $\mathrm{C}$ was the most frequently in all the examined ready-to-eat sandwiches, indicating that $S$. aureus had a potential public health significance in fast food.

Key words: S. aureus, MRSA, hawawshy, kofta, liver, shawarma, enterotoxin.

\section{INTRODUCTION}

Nowadays, meat products consumed as sandwiches of shawarma, kofta, hawawshy, etc. are commonly prepared and sold by many restaurants which are widely distributed all over the country (Takeaway). Staphylococcus aureus (S. aureus) is one of the most important microorganisms which can contaminate or recontaminate cooked foods via workers hands, equipments or utensils (Bryan, 1988).

S. aureus is a cluster forming spherical Gram-positive bacterium which is known to cause food-borne intoxication, as some of its pathogenic strains are capable of producing heat-stable enterotoxins. Although this facultative anaerobic bacterium possesses a wide spectrum of virulence properties, including extracellular proteins like adhesions, invasions, hemolysins, extoxins, etc., staphylococcal enterotoxins (SEs) are recognized as the most important factors for its pathogenicity. The production of SE by this bacterium is recognized as one of the predominant food-borne problems causing gastroenteritis worldwide. Contamination by toxigenic $S$. aureus in ready-to-eat food is a major 
public health issue in both developing countries like Vietnam and developed countries like the USA, Japan, etc. During 1997, approximately 185,000 people suffered from the SE related foodpoisoning including thousand of deaths (Mead et al., 1999).

Staphylococcal food poisoning (SFP) is a mild intoxication occurring after the ingestion of food containing from $20 \mathrm{ng}$ to $<1 \mu \mathrm{g}$ of staphylococcal entertoxin (SE), enough to determine symptoms in human beings (Berdgoll, 1989). SFP symptoms appear within a few hours (i.e. 1-6 h) after ingestion of contaminated food, depending on individual susceptibility and toxic dose ingested. They include nausea, abdominal cramps, diarrhea and a characteristic projectile vomiting (Le Loir et al., 2003).

Lack of proper hygienic measures during food preparation is one of the major sources of contamination as the food-handlers themselves can harbor the pathogenic bacterium. Besides, S. aureus can tolerate a wide range of temperature, $\mathrm{pH}$ and salinity (Stewart et al., 2002). Proper understanding and extensive knowledge about the routes of $S$. aureus contamination is important for the effective control of related disease outbreaks.

Most of the nosocomial $S$. aureus infections are caused by methicillin-resistant $S$. aureus (MRSA) strains and have become a widely recognized cause of morbidity and mortality throughout the world (Ho et al., 2008). In addition, MRSA strains resistant to quinolones or multiresistant to other antibiotics have been emerging, leaving a limited choice for their control (Pesavento et al., 2007). Furthermore, community acquired MRSA infection has been reported in 2001, when a family was involved in an outbreak from ingestion of MRSA with baked meat, contaminated from the food handler (Jones et al., 2002).

Various ready-to-eat products are becoming increasingly popular in this developing country, particularly in the metropolitan areas. The occurrence and patterns of enterotoxigenic $S$. aureus in ready-to-eat food products has been reported from different parts of the world including South East Asian countries like Taiwan, South Korea, Thailand, etc. (Chomvarin et al., 2006; Oh et al., 2007; Chiang et al., 2008). Therefore, the present work was conducted to investigate the incidence of enterotoxigenic S. aureus and methicillin-resistant S. aureus (MRSA) strains in different popular ready-to-eat sandwiches (hawawshy, kofta, liver and shawarma) in Assuit city as well as to determine the prevalence of the major SEs among the isolated $S$. aureus strains. 


\section{MATERIALS and METHODS}

\section{1- Collection of samples:}

A total of 80 random samples of ready-to-eat sandwiches were collected from different fast food restaurants with different sanitation levels in Assuit City. Sandwiches types evaluated were hawawshy, kofta, liver and shawarma (20 of each). All samples were directly transferred to the laboratory in an ice box under hygienic conditions without delay to be examined bacteriologically.

\section{2- Preparation of samples: (APHA, 1992)}

Ten grams of each meat product sample only without bread were homogenized aseptically for $1 \mathrm{~min}$ with $90 \mathrm{ml}$ of $0.1 \%$ peptone water in a stomacher (Colworth, 400). It was then serially diluted 10-fold in the same diluent.

\section{3- Determination of $S$. aureus count: (AOAC, 2000)}

$0.1 \mathrm{ml}$ from each of the prepared dilutions was spread onto duplicate plates of Baird-Parker (BP) agar (Oxoid CM 275), supplemented with egg yolk tellurite emulsion $(50 \mathrm{ml} / \mathrm{L}$, Oxoid SR54) and incubated at $37^{\circ} \mathrm{C}$ for $24-48 \mathrm{~h}$. Colonies with typical $S$. aureus morphology (i.e., circular, black, shiny with narrow white margins and surrounded by clear zones extending into the opaque medium) were counted and recorded.

\section{4- Isolation of $S$. aureus:}

\section{Enrichment procedures: (Lee, 2003)}

Ten grams of each meat product samples were inoculated into $100 \mathrm{ml}$ of staphylococcus broth (Difco, 264920) and incubated at $35^{\circ} \mathrm{C}$ for $20 \mathrm{~h}$ with shaking.

\section{Selective plating:}

A loopful from the incubated broth was streaked onto BairdParker agar (Thatcher and Clarck, 1975) and incubated at $37^{\circ} \mathrm{C}$ for $24 \mathrm{~h}$. Suspected colonies were subcultured on slants of Brain Heart Infusion (BHI) agar (Oxoid CM225) and incubated at $37^{\circ} \mathrm{C}$ for $24 \mathrm{~h}$ before being subjected to identification.

\section{Identification of isolates:}

Isolated purified strains were identified morphologically by Gram's stain and biochemically confirmed as $S$. aureus according to FDA (2001) by the conventional methods that included catalase, production of coagulase and anaerobic utilization of glucose and mannitol. 


\section{5- Isolation of MRSA: (Simor et al., 2001)}

The isolated strains of $S$. aureus were streaked onto Oxacillin Resistance Screening Agar Base (ORSAB) (Oxoid, CM1008) supplemented with ORSAB selective supplement (Oxoid, SR0195). The plates were incubated at $37^{\circ} \mathrm{C}$ for $24-48 \mathrm{~h}$ and examined for the presence of blue colonies.

\section{6- Detection of staphylococcal enterotoxins: (Park et al., 1994)}

Production of enterotoxins A, B, C, D and E was determined by a RIDASCREEN kit (R- Biopharm, R4101) according to the manufacturer's instructions. A colony of MRSA was incubated in Brain Heart Infusion broth (Oxoid, CM1032) for $12 \mathrm{~h}$ at $37^{\circ} \mathrm{C}$. The culture was centrifuged and the supernatants were tested for enterotoxin production.

\section{RESULTS}

The obtained results are recorded in Tables 1-4

Table 1: Statistical values of $S$. aureus count/g of the examined readyto-eat sandwiches (No. $=20$ of each)

\begin{tabular}{|l|c|c|c|c|c|}
\hline \multicolumn{1}{|c|}{$\begin{array}{c}\text { Examined } \\
\text { samples }\end{array}$} & \multicolumn{2}{|c|}{ Positive samples } & \multirow{2}{*}{ Min. } & Max. & Average \\
\cline { 2 - 3 } & No. & \multicolumn{2}{c|}{$\%$} & & \\
\hline Hawawshy & 4 & 20.0 & $5 \times 10^{2}$ & $8.7 \times 10^{3}$ & $2.75 \times 10^{2}$ \\
\hline Liver & 6 & 30.0 & $7 \times 10^{2}$ & $8.6 \times 10^{4}$ & $2.8 \times 10^{4}$ \\
\hline Kofta & 7 & 35.0 & $7 \times 10^{2}$ & $2 \times 10^{5}$ & $7.2 \times 10^{4}$ \\
\hline Shawarma & 5 & 25.0 & $41 \times 0^{2}$ & $3 \times 10^{4}$ & $8.98 \times 10^{3}$ \\
\hline
\end{tabular}

Table 2: Incidence of $S$. aureus in the examined ready-to-eat sandwiches

\begin{tabular}{|l|c|c|c|}
\hline \multirow{2}{*}{ Examined samples } & \multirow{2}{*}{$\begin{array}{c}\text { No. of examined } \\
\text { samples }\end{array}$} & \multicolumn{2}{|c|}{ Positive samples } \\
\cline { 3 - 4 } & 20 & No. & $\%$ \\
\hline Hawawshy & 20 & 5 & 25.0 \\
\hline Liver & 20 & 8 & 45.0 \\
\hline Kofta & 20 & 6 & 40.0 \\
\hline Shawarma & 80 & 28 & 30.0 \\
\hline Total & & & \\
\hline
\end{tabular}


Table 3: Incidence of MRSA strains isolated from the examined readyto-eat sandwiches

\begin{tabular}{|l|c|c|c|}
\hline \multirow{2}{*}{$\begin{array}{c}\text { Examined } \\
\text { samples }\end{array}$} & \multirow{2}{*}{$\begin{array}{c}\text { Number of } \\
\text { examined } \\
\text { samples }\end{array}$} & \multicolumn{2}{c|}{ Positive samples } \\
\cline { 3 - 4 } Hawawshy & 20 & 3 & $\%$ \\
\hline Liver & 20 & 8 & 15.0 \\
\hline Kofta & 20 & 7 & 40.0 \\
\hline Shawarma & 20 & 5 & 35.0 \\
\hline Total & 80 & 23 & 25.0 \\
\hline
\end{tabular}

Table 4: Distribution of multiple enterotoxins produced by some strains of $S$. aureus isolated from ready-to-eat sandwiches

\begin{tabular}{|l|c|c|c|c|c|c|c|c|}
\hline \multirow{2}{*}{ Product } & \multirow{2}{*}{$\begin{array}{l}\text { No.of } \\
\text { strains } \\
\end{array}$} & \multirow{2}{*}{$\begin{array}{c}\text { No. of } \\
\text { strains } \\
\text { tested } \\
\end{array}$} & & \multicolumn{4}{|c|}{ Types of produced enterotoxins } \\
\cline { 5 - 9 } & enterotoxins & C & CD & CE & ACD & ACE & ABCDE \\
\hline Hawawshy & 2 & 0 & - & - & - & - & - & - \\
\hline Liver & 4 & 4 & 3 & - & - & - & 1 & - \\
\hline Kofta & 3 & 1 & - & - & 1 & - & - & - \\
\hline Shawarma & 3 & 3 & - & 1 & - & 1 & - & 1 \\
\hline
\end{tabular}

\section{DISCUSSION}

The results recorded in Table 1 revealed that the average counts of $S$. aureus in the examined ready-to-eat meat sandwiches were $2.75 \times 10^{3}, 2.8 \times 10^{4}, 7.2 \times 10^{4}$ and $8.98 \times 10^{3} \mathrm{cfu} / \mathrm{g}$ in hawawshy, liver, kofta and shawarma, respectively.

The four ready-to-eat products whose staphylococcal isolates were investigated were found earlier to be highly contaminated with staphylococci. Aycicek et al. (2005) reported that meatballs and liver samples contained $S$. aureus with counts ranging from 3.7-4.1 and 2.5$3.6 \log \mathrm{cfu} / \mathrm{g}$, respectively. In Egypt, EL-Mossalami et al. (2008) mentioned that shawarma and liver sandwiches have $S$. aureus with counts ranged from $3.4 \times 10^{2}$ to $5.2 \times 10^{4}$ and $3.7 \times 10^{2}$ to $6 \times 10^{4} \mathrm{cfu} / \mathrm{g}$, respectively. While, Shalaby and Zaki (2008) could detect $S$. aureus in shawarma in numbers varied from $2 \times 10^{2}$ to $3 \times 10^{3}$ with a mean value of $9.8 \times 10^{2} \mathrm{cfu} / \mathrm{g}$. 
According to the US Food and Drug Administration (http://www.cfsan.fda.gov/ mow/ chap3.html.Food), $\geq 10^{5} \quad$ CFU/g S. aureus is capable of causing staphylococcal intoxication. A simulation model of risk assessment has shown that only few cells in ready-to-eat food can have 3-4 log increases at ambient temperature within $5 \mathrm{~h}$ (Rho and Schaffner, 2007). The number of $S$. aureus population in the observed ready-to-eat food samples are lower than the required dose to induce food-borne illness but some foods can be considered to have potential risk as there are chances of the bacterium's multiplication during the time of food poisoning as well as if these foods are kept at room temperature for long time in tropical climate.

Out of 80 ready-to-eat samples examined, 28 (35.0\%) were found to be contaminated with S. aureus (Table 2). Liver samples showed the highest prevalence (9 out of 20;45\%) of S. aureus contamination. The bacterium was detected in 25,40 and $30 \%$ of hawawshy, kofta and shawarma sandwiches, respectively.

Thus our study revealed a comparatively higher prevalence of $S$. aureus in the examined samples. However, the ready-to-eat food items possessed risk of contamination as they were exclusively prepared by small-scale local producers without quality control checking for bacterial pathogens. Improper handling and possible crosscontamination during transportation and storage is also possible. Besides, re-used or improperly washed containers or equipment and primary packaging can also be sources of contamination. A recent study in Botswana reported that $57.5 \%$ of the food handlers harbored S. aureus bacterium and $21 \%$ of them possessed toxigenic strains (Loeto et al., 2007).

Regarding the incidence of $S$. aureus recorded in Table 2, the obtained results were less than those obtained by EL-Mossalami et al. (2008) who isolated the organism from 22 (88\%) and 20 (80\%) of readyto-eat shawarma and liver sandwiches, respectively, and higher than those obtained by Soriano et al. (2002) who detected S. aureus in $16.9 \%$ of meatballs samples and Aycicek et al. (2005) who isolated the bacterium from $17(11.8 \%)$ and $3(9.4 \%)$ of meatballs and liver sandwiches, respectively. Moreover, similar results recorded by Shalaby and Zaki (2008) who reported that $32 \%$ of the examined shawarma samples were contaminated with $S$. aureus.

According to our results, a high frequency of methicillin resistance was encountered for $S$. aureus strains isolated from liver (40\%), kofta (35\%), shawarma (25\%) and hawawshy (15\%) (Table 3). 
The results of the present study highlighted that; these foods may constitute a risk for consumers and especially for immunocompromised individuals. In immunocompromised persons the specific and nonspecific immune responses are not able to act as barriers to prevent colonization of the gastrointestinal tract and ingestion of food contaminated by MRSA may lead to sometimes lethal disease (Kluytmans et al., 1995).

SFP is one of the most common causes of food-borne illness due to the widespread occurrence of $S$. aureus and to the ability of many strains to synthesize one or more SEs. Inspection of Table 4 revealed that out of 12 methicillin resistance $S$. aureus strains tested for enterotoxins production 8 strains possessed the targeted classical SEs. In liver, all four tested strains were enterotoxigenic where 3 of them were type $\mathrm{C}$ enterotoxins and one strain produced ACE enterotoxins. Also, all three tested strains in shawarma were enterotoxigenic, 1(CD), 1(ACD) and 1 (ABCDE). One the other side, the strains isolated from hawawshy failed to produce any enterotoxins. Moreover, from the 3 strains of S. aureus isolated from kofta only one strain had the ability to produce enterotoxin CE.

The distribution of the types of SE produced is quite different from those reported in the literature because in our material the SEC is predominantly produced. Similar results reported by Normanno et al. (2005) who found that most of the isolates isolated produced SEC (33.9\%) and Rosec et al. (1997) stated that enterotoxin C was produced by $66 \%$ of the enterotoxigenic strains, singly or in combination with other enterotoxins.

Considering the importance and public health hazard of $S$. aureus organism recovered from fast food (ready-to-eat sandwiches), Longree and Blacker (1971) reported that preparing and serving food to the public is a very important obligation that can only be fulfilled if every one in the establishment understand food hygiene, applying sanitary measures at every stage of the operation. Furthermore, ICMSF (1988) stated that cooked meat should not be touched by hands or by equipments that have come in contact with raw meat; raw products should be separated from cooked products to avoid cross-contamination.

To safe the ready-to-eat sandwiches sold in fast food services it must be focus on prevention of contamination and multiplication of microbes and production of toxins. Food should not be prepared long in advance of consumption (Bryan et al., 1992). Cooking usually give time temperature exposures that would have been lethal for vegetative form 
of food-borne pathogens. On the other hands, holding of food provide time temperature exposures conductive to microbial growth, particularly in food holds overnight and large populations of aerobic organisms including S. aureus and others were recovered from these food. So, time temperature had variable effect of killing the microorganism but heat stable toxins still not affected (Jermini et al., 1997 and Pepe et al., 2006). In conclusion, it can be achieved from the obtained data that fast meat products (sandwiches) have the potential to cause staphylococcal intoxication to consumers. So, the rules of health agencies must reach to all workers in such field especially street vendors and fast food takeaway restaurants besides safety programs for safe food preparation drawn by WHO (1989) should be followed and effective preventive measures must be authorized and applied to safe the consumer health.

\section{REFERENCES}

A.O.A.C. "Association of Official Analytical Chemists" (2000): Official Methods of Analysis. Food composition, additives and contamination. $7^{\text {th }}$ Ed., Vol. 2. Public Association of Official Analytical Chemists, North Frederick Avenue, Gaithersburg, Maryland, USA.

A.P.H.A. "American Puplic Health Association" (1992): Standard Methods for the Examination of Dairy Products. $16^{\text {th }}$ Ed., American Public Health Association. New York.

Aycicek, H.; Cakiroglu, S. and Stevenson, T.H. (2005): Incidence of Staphylococcus aureus in ready-to-eat meals from military cafeterias in Ankara, Turkey. Food Control, 16: 531-534.

Berdgoll, M.S. (1989): Staphylococcus aureus. In: Doyle, M.P. (Ed.), Food- Borne Bacterial Pathogens. Marcel Dekker, New York, pp: 464-523.

Bryan, F.L. (1988): Risks associated with vehicles of foodborne pathogens and toxins. J. Food Prot., 51: 498-508.

Bryan, F.L.; Teufel, P.; Riaz, S.; Qadar, F. and Malike, J. (1992):

Hazards and critical control points of vending operations at a railway station and a bus station in Pakistan. J. Food Prot., 55: 534-541.

Chiang, Y.C.; Liao, W.W.; Fan, C.M.; Pai, W.Y.; Chiou, C.S. and Tsen, H.Y. (2008): PCR detection of Staphylococcal enterotoxins (SEs)N,O, P, Q, R, U and survey of SE types in Staphylococcus 
aureus isolates from food-poisoning cases in Taiwan. Int. J. Food Microbiol., 15:66-73.

Chomvarin, C.; Chantarasuk, Y.; Srigulbutr, S.; Chareonsudjai, S. and Chaicumpar, K. (2006): Enteropathogenic bacteria and enterotoxin-producing Staphylococcus aureus isolated from ready-to-eat foods in Khon Kaen, Thailand. Southeast Asian J. Trop. Med. Public Health, 37: 983-990.

EL-Mossalami, Hanaa, H.A.; Abd-EL-Rahman, A.A. and Magdy, E.M. (2008): A study on the effect of garlic and nigella sativa on some food poisoning bacteria isolated from ready-to-eat meat sandwiches in Alexandria city. Assiut Vet. Med. J., 54: 140-158.

FDA "Food and Drug Administration" (2001): Bacteriological Analytical Manuaal $8^{\text {th }}$ Ed., Arlington, Virginia, Association of Analytical Chemists.

Ho, P.; Chuang, S.; Choi, Y., Lee, R.A.; Lit, A.C.H.; Ng, T.; Que, T.; Shek, K.; Tong, H.; Tse, C.W.S.; Tung, W. and Yung, R.W.H. (2008): Community-associated methicillin-resistant and methicillin-sensitive Staphylococcus aureus: skin and soft tissue infections in Hong Kong. Diagn. Microbiol. Infect. Dis., 61: 245250.

ICMSF "International Commission on Microbiological Specification for Food" (1988): "Microorganisms in food.4. Application of the hazard analysis critical control point (HACCP) system to ensure microbial safety and quality". Blackwell, Oxford, Londen.

Jermini, M.; Bryan, F.L.; Schmitt, R.; Mwande, C.; Mweya, J.; Zyuulu, M.H.; Matoba, E.N.; Hakalina, A.T. and Mwanza, M. (1997): Hazards and Critical Control points of food vending operations in city in Zambia. J. Food Prot., 67: 1433-1437.

Jones, T.F.; Kellum, M.E.; Porter, S.S.; Bell, M. and Schaffner, W. (2002): An outbreak of community-acquired foodborne illness caused by methicillin-resistant Staphylococcus aureus. Emerg. Infect. Dis., 8: 82-84.

Kluytmans, J.; Van Leeuwen, W.; Goessens, W.; Hollis, R.; Messer, S.; Herwarld, L.; Bruining, H.; Heck, M.; Rost, J.; Van Leeuwen, N.; Van Belkum, A. and Verbrugh, H. (1995): Food-initiated outbreak of methicillin resistant Staphylococcus aureus analyzed by phenol and genotyping. J.Clin. Microbiol., 33: 1121-1128.

Lee, J. (2003): Methicillin (Oxacillin) resistant Staph. aureus strains isolated from major food animals and their potential transmission to humans. Appl. Environ. Microbiol., 69: 6489-6494. 
Le Loir, Y.; Baron, F. and Gautier, M. (2003): Staphylococcus aureus and food poisoning. Genet. Mol. Res., 2: 63-67.

Loeto, D.; Matsheka, M.I. and Gashe, B.A. (2007): Enterotoxigenic and antibiotic resistance determination of Staphylococcus aureus strains isolated from food handlers in Gaborone, Botswana. J. Food Prot., 70: 2764-2768.

Longree, K. and Blacker, G.G. (1971): "Sanitary techniques in food service." John Wiley and Sons, Inc., New York.

Mead, P.S.; Slutsker, L.; Dietz, V.; McCaig, L.F.; Bresee, J.S. and Shapiro, C., et al. (1999): Food-related illness and death in the United States. Emerg. Infect. Dis., 5: 607-625.

Normanno, G.; Firinu, A.; Virgilio, S.; Mula, G.; Dambrosio, A.; Poggiu, A.; Decastelli, L.; Mioni, R.; Scuota, S.; Bolzoni, G.; Di Giannatale, E.; Salinetti, A.P.; La Salandra, G.; Bartoli, M.; Zuccon, F.; Pirino, T.; Sias, S.; Parisi, A.; Quaglia, N.C. and Celano, G.V. (2005): Coagulase-positive staphylococci and Staphylococcus aureus in food products marketed in Italy. Int. J. Food Microbiol., 98: 73-79.

Oh, S.K.; Lee, N.; Cho, Y.S.; Shin, D.B.; Choi, S.Y. and Koo, M. (2007):

Occurrence of toxigenic Staphylococcus aureus in ready-to-eat food in Korea. J. Food Prot., 70: 1153-1158.

Park, C.E.; Akhtar, M. and Rayman, M.K. (1994): Evaluation of a commercial enzyme immunoassay kit (RIDASCREEN) for detection of staphylococcal enterotoxins A, B, C, D, and E in foods. Appl. Environ. Microbiol., 60: 677-681.

Pepe, O.; Blaiotta, G.; Bucci, F.; Anastasio, M.; Aponte, M. and Villani, F. (2006): Staphylococcus aureus and Staphylococcal Enterotoxin A in Breaded Chicken Products: Detection and Behavior during the Cooking Process. Appl. Environ. Microbiol., 72: 7057-7062.

Pesavento, G.; Ducci, B.; Comodo, N. and Nostro, A.L. (2007): Antimicrobial resistance profile of Staphylococcus aureus isolated from raw meat: a research for methicillin resistant Staphylococcus aureus (MRSA). Food Control, 18: 196-200.

Rho, M.J. and Schaffner, D.W. (2007): Microbial risk assessment of staphylococcal food poisoning in Korean kimbab. Int. J. Food Microbiol., 116: 332-338.

Rosec, J.P.; Guiraud, J.P.; Dalet, C. and Richard, N. (1997): Enterotoxin production by staphylococci isolated from foods in France. Int. J. Food Microbiol., 37: 213 -221. 
Shalaby, Amany, M. and Zaki, Eman, M.S. (2008): Occurrence of Staphylococcus aureus in fast food with special reference to its enterotoxigenicity. Assiut Vet. Med. J., 54: 37-50.

Simor, A.E.; Goodffellow, J.; Louie, L. and Louie, M. (2001): Evaluation of a new medium, Oxacillin Resistance Screening Agar Base, for the detection of methicillin resistant Staph. aureus from clinical specimens. J. Clin. Microbiol., 39: 3422.

Soriano, J.M.; Blesa, J.; Rico, H.; Molto, J.C. and Manes, J. (2002): Incidence of Staphylococcus aureus in meals from cafeterias. J. Food Safety, 22: 135-140.

Stewart, C.M.; Cole, M.B.; Legan, J.D.; Slade, L.; Vandeven, M.H. and Schaffner, D.W. (2002): Staphylococcus aureus growth boundaries: moving towards mechanistic predictive models based on solute-specific effects. Appl. Environ. Microbiol., 68: 1671-1864.

Thatcher, F.S. and Clarck, D.S. (1975): Microorganisms in Foods. International Committee on Microbiological Specification for Foods. Univ. Toronto Press., Toronto, Canada.

WHO "World Health Organization" (1989): "The WHO golden rules for safe food preparation." New litter, Institute of Veterinary Medicine, Robert Von Ostertag Institute, FAO/WHO Collaborating Center for Research and training in Food Hygiene and Zoonoses, Berlin West. 